\title{
Testing of Hybrid Vigour for Sex Phenology in Cucumber (Cucumis sativus L.).
}

\author{
Prashant R. Naik ${ }^{1 *}$, Nagarajappa Adivappar ${ }^{2}$, V. Srinivasa ${ }^{1}$ and S. Gangaprasad ${ }^{3}$ \\ ${ }^{1}$ Department of Vegetable Science, College of Horticulture, Mudigere-577132, India \\ ${ }^{2}$ ZAHRS, Navule, Shivamogga-577204, India \\ ${ }^{3}$ Department of Genetics and Plant Breeding, College of Agriculture, Navule, \\ Shivamogga-577204, India \\ *Corresponding author
}

\section{A B S T R A C T}

\begin{tabular}{|l|}
\hline Ke y w o r d s \\
Cucumber, Lines, \\
Tester, Heterosis, \\
Heterobeltiosis \\
\hline Article Info \\
\hline $\begin{array}{l}\text { Accepted: } \\
\text { 15 January } 2019 \\
\text { Available Online: } \\
\text { 10 February } 2019\end{array}$ \\
\hline
\end{tabular}

\begin{abstract}
Studies on heterosis in cucumber (Cucumis sativus L.) was undertaken at ZAHRS, Navule, Shivamogga district, Karnataka during kharif and rabi seasons of year 2016-17. A total of 27 crosses were developed by crossing with nine lines with each of three testers. All the crosses were evaluated along with the parents in randomized block design with two replications. The hybrid Pebkamal $\times$ Haveri Local reported the significant negative heterobeltiosis for days to first female flower appearance, node at which first male and female flower appear. The hybrids US-640 $\times$ Haveri Local exhibited the significant negative heterosis for days to first harvest over both checks. The cross NCU-1287 $\times$ Belgum Local exhibited the significant negative heterobeltiosis $(-10.64 \%)$ as well as standard heterosis $(-8.70 \%)$ over the check Poinsette. All the crosses made DWD and Himangi as female parent exhibit the desirable significant positive heterosis for days to last harvest.
\end{abstract}

\section{Introduction}

India is regarded as primary centre of origin of cucumber (Cucumis sativus L.) and exhibits rich genetic diversity along the country starts from south-east foot hills of Himalaya to southern peninsular. Original sex form of cucumber is hermaphrodite and present cultivated sex form is monoecious in open condition. Sex expression in cucumber is regulated by environmental, genetic and hormonal factors. In general, female sex expression is promoted by low temperature, short photoperiod etc., which may influence the level of endogenous hormones which in turn influence the sex expression (Agbaje et al., 2012).

Apart from this sex forms and flowering sequence can be manipulated to a little extent by exploiting heterosis for sex phenology. The exploitation of heterosis is much easier in cross pollinated crops, cucumber being monoecious and poses more seed per cross, 
provides ample scope for the utilization of hybrid vigour on commercial scale.

\section{Materials and Methods}

Nine genetically diverse genotypes viz., Himangi, Sabra, US-640, Phule Shubhangi, NCU-1287, Pebkamal, Dharwad Collection (DWD), US646, Honnavara Collection (Hnr) and three tester viz., Haveri Local, Belgum Local and Bagalkot Local were used to produce 27 hybrids. All the crosses and their parents along with standard check 'Poinsette' were sown in randomized block design with two replications during rabi and summer, 2016 at Zonal Agriculture and Horticulture Research Station (ZAHRS), Navule, Shivamogga, Karnataka. The crop was raised as per the package of practices (Anon., 2015). The observations were recorded on five randomly selected plants for seven important earliness parameters viz., days to first male flower, Node at male flower appear, Days to first female appear. Node at female flower appear, $50 \%$ flowering, $100 \%$ flowering, Days to first harvest and Days to last harvest.

Heterosis in positive direction is desirable for yield and its attributing traits. It is measured as percentage increase of $F_{1}$ performance over better parent (BP), standard checks Poinsette (SC1) and Malini (SC2).

\section{Results and Discussion}

The sequence of flowering in cucurbits follows the first male phase followed by female phase and mixed phase for shorter period (Bhakti et al., 2016). Hence, first male flower appear were indicates the earliness parameter. Very little standard heterosis for this trait was observed and none of the crosses exhibited the significant heterobeltiosis in both directions. Only cross NCU-1287 $\times$ Belgum Local exhibited the significant heterosis over both the checks (Table 1), similarly positive standard heterosis was reported by Singh and Ram (2009) in cucumber.

Flowering at lower node is an indication of earliness. In cucurbits male flower appear at the lower node, usually 6-7 days before the female flower open. Hence, appearance of male flower is related with earliness. Heterosis in negative direction was desirable for node at first flower appear, the cross US$640 \times$ Haveri Local exhibited the significant negative heterosis over both checks. Similar standard heterosis was recorded by Singh and Ram (2009) in cucumber. Five crosses viz., Himangi $\times$ Haveri Local (-16.46 \%), US-640 $\times$ Haveri Local $(-36.11 \%)$, Pebkamal $\times$ Haveri Local (-34.48\%), DWD $\times$ Belgum Local ($17.07 \%)$ and DWD $\times$ Bagalkot Local ($15.29 \%$ ) exhibited the significant negative heterobeltiosis for node at first male flower appear. This result is in line with research findings of Singh et al., (2010), Mule et al., (2012) and Singh et al., (2015) in cucumber. The hybrids US-640 $\times$ Haveri Local $(-9.32 \%)$ and Pebkamal $\times$ Haveri Local $(-12.66 \%)$ exhibited the significant negative heterosis for days to first female flower appear. The reason for significant negative heterosis may be due to the presence of dominant loci in different directions leading to cancellation of effects (Pandey et al., 2005). Crosses not shown significant negative heterosis over commercial checks and few crosses exhibited the significant negative heterosis over better parent. The crosses showing no heterosis indicated that the parent involved in the cross do not differ in the gene frequency with respect the character under study (Pandey et al., 2005). Appearance of first female flower at lower node is prime objective in development of early hybrid. For the development of early fruiting genotypes, negative heterosis is desirable for node number at which first female flower appear (Arya and Singh, 2014). 
Table.1 Per cent heterosis for earliness parameter in cucumber

\begin{tabular}{|c|c|c|c|c|c|c|c|c|c|c|c|c|}
\hline \multirow[t]{2}{*}{ Hybrids } & \multicolumn{3}{|c|}{ Days to first male flowe } & \multicolumn{6}{|c|}{ Node at male flower appear Days to first female } & \multicolumn{3}{|c|}{ Node at female flower appear } \\
\hline & BP & SC1 & SC2 & BP & SC1 & $\mathrm{SC2}$ & BP & SC1 & SC2 & BP & SC1 & $\mathrm{SC2}$ \\
\hline Himangi $\times$ Haveri Local & 2.43 & 2.74 & 5.97 & $-16.46^{*}$ & 1.54 & 8.20 & -0.27 & 2.23 & 9.23 & -15.69 & 4.88 & -2.27 \\
\hline Himangi $\times$ Belgum Local & 6.69 & 7.01 & 10.38 & -8.86 & 10.77 & 18.03 & 8.70 & $11.42 *$ & $19.05 * *$ & -15.79 & 17.07 & 9.09 \\
\hline Himangi $\times$ Bagalkot Local & 6.96 & 7.01 & 10.38 & -11.76 & 15.38 & $22.95^{*}$ & 1.50 & 8.64 & $16.07 * *$ & 1.89 & 31.71 & 22.73 \\
\hline Sabra $\times$ Haveri Local & -0.28 & 8.23 & $11.64 *$ & $22.22 * *$ & $35.38 * *$ & $44.26 * *$ & -0.50 & $11.70 *$ & $19.35 * *$ & $36.36^{*}$ & $46.34 *$ & $36.36^{*}$ \\
\hline sabra $\times$ Belgum Local & -4.78 & 3.35 & 6.60 & 6.33 & $29.23 * *$ & $37.70 * *$ & -3.72 & 8.08 & $15.48 * *$ & -8.77 & 26.83 & 18.18 \\
\hline Sabra $\times$ Bagalkot Local & 3.37 & 12.20 & $15.72 *$ & 0.00 & $30.77 * *$ & $39.34 * *$ & 0.99 & $13.37 * *$ & $21.13 * *$ & 13.21 & $46.34 *$ & $36.36^{*}$ \\
\hline US-640 $\times$ Haveri Local & -6.40 & -6.40 & -3.46 & $-36.11 * *$ & $-29.23 * *$ & $-24.59 *$ & $-9.32 *$ & -7.80 & -1.49 & $-31.82 *$ & -28.83 & $-31.82 *$ \\
\hline US640 $\times$ Belgum Local & 0.30 & 0.30 & 3.46 & -8.86 & 10.77 & 18.09 & 2.74 & 4.46 & 11.61 & -15.79 & 17.07 & 9.09 \\
\hline US640 $\times$ Bagalkot Local & .000 & 0.00 & 3.14 & -10.59 & 16.92 & $24.59 *$ & -4.17 & 2.51 & 9.52 & -11.32 & 14.63 & 6.82 \\
\hline Phule Shubhangi $\times$ Haveri Local & 1.71 & 8.54 & $11.95^{*}$ & -5.13 & 13.85 & $21.31 *$ & -1.00 & $10.31 *$ & $17.86 * *$ & -1.85 & 29.27 & 20.45 \\
\hline Phule Shubhangi $\times$ Belgum Local & -3.71 & 2.74 & 5.97 & 10.13 & $33.85 * *$ & $42.62 * *$ & -4.25 & 6.69 & $13.99 * *$ & -3.51 & 34.15 & 25.00 \\
\hline Phule Shubhangi $\times$ Bagalkot Local & -0.86 & 5.79 & 9.12 & 1.18 & $32.31 * *$ & $40.98 * *$ & -1.00 & $10.31 *$ & $17.86 * *$ & 1.85 & 34.15 & 25.00 \\
\hline NCU-1287 × Haveri Local & -0.29 & 5.18 & 8.49 & -7.41 & 15.38 & $22.95 *$ & -2.05 & 6.41 & $1.69 * *$ & -3.85 & 21.95 & 13.64 \\
\hline NCU-1287 × Belgum Local & 8.67 & $14.63 *$ & $18.24 * *$ & 2.47 & $27.69 * *$ & $36.07 * *$ & 4.62 & $13.65 * *$ & $21.43 * *$ & 3.51 & $43.90 *$ & $34.09 *$ \\
\hline NCU-1287 $\times$ Bagalkot Local & 4.34 & 10.06 & $13.52 *$ & 1.18 & $32.31 * *$ & $40.98 * *$ & 2.31 & $11.14^{*}$ & $18.75 * *$ & 5.66 & $36.59 *$ & 27.27 \\
\hline Pebkamal × Haveri Local & -8.52 & -1.83 & 1.26 & $-34.48 * *$ & -12.31 & -6.56 & $-12.66 * *$ & -1.95 & 4.76 & $-36.21 * *$ & -9.76 & -15.91 \\
\hline Pebkamal $\times$ Belgum Local & 1.24 & 8.84 & $12.26^{*}$ & -2.30 & $30.77 * *$ & $39.34 * *$ & -2.23 & $9.75^{*}$ & $17.26 * *$ & -5.17 & 34.15 & 25.00 \\
\hline Pebkamal $\times$ Bagalkot Local & -2.27 & 4.88 & 8.18 & -2.30 & $30.77 * *$ & $39.34 * *$ & -3.72 & 8.08 & $15.48 * *$ & -6.90 & 31.71 & 22.73 \\
\hline DWD $\times$ Haveri Local & -0.62 & -2.74 & 0.31 & -1.22 & $24.62 * *$ & $32.79 * *$ & -2.08 & 5.01 & $12.20 *$ & -15.00 & 24.39 & 15.91 \\
\hline DWD $\times$ Belgum Local & -5.30 & -7.32 & -4.40 & $-17.07 *$ & 4.62 & 11.48 & -7.27 & 0.56 & 6.25 & $-28.33 *$ & 4.88 & -2.27 \\
\hline DWD $\times$ Bagalkot Local & -1.87 & -3.96 & -0.94 & $-15.29 *$ & 10.77 & 18.03 & 0.00 & 7.24 & $14.58 * *$ & -18.33 & 19.51 & 11.36 \\
\hline US-646 × Haveri Local & -1.18 & 2.13 & 5.35 & -12.00 & 1.54 & 8.20 & -2.94 & 1.11 & 8.04 & -16.67 & -2.44 & -9.09 \\
\hline US-646 × Belgum Local & 1.47 & 4.48 & 8.18 & -3.80 & 16.92 & $24.59 *$ & 4.28 & 8.64 & $16.07 * *$ & -10.53 & 24.39 & 15.91 \\
\hline US-646 $\times$ Bagalkot Local & -7.52 & -4.42 & -1.42 & -12.94 & 13.85 & $21.31 *$ & 1.30 & 8.36 & $15.77 * *$ & 0.00 & 29.27 & 20.45 \\
\hline Hnr × Haveri Local & 2.02 & 7.62 & 11.01 & -10.47 & $18.46^{*}$ & $26.23 * *$ & -2.00 & $9.19 *$ & $16.67 * *$ & -3.57 & 31.17 & 22.73 \\
\hline Hnr $\times$ Belgum Local & 2.31 & 7.93 & 11.32 & -6.98 & $23.08 *$ & $31.15 * *$ & -2.00 & $9.19 *$ & $16.67 * *$ & 1.75 & 41.46 & 31.82 \\
\hline Hnr $\times$ Bagalkot Local & 1.16 & 6.71 & 10.06 & -1.16 & $30.77 * *$ & $39.34 * *$ & -0.50 & $10.86 *$ & $18.45 * *$ & 3.57 & 41.46 & 31.82 \\
\hline S.Em \pm & 1.76 & 1.76 & 1.76 & 1.79 & 1.79 & 1.79 & 1.56 & 1.56 & 1.56 & 0.68 & 0.68 & 0.68 \\
\hline CD@ 5\% & 3.61 & 3.61 & 3.61 & 3.68 & 3.68 & 3.68 & 3.20 & 3.20 & 3.20 & 1.41 & 1.41 & 1.41 \\
\hline CD@ 1\% & 4.89 & 4.89 & 4.89 & 4.97 & 4.97 & 4.97 & 4.33 & 4.33 & 4.33 & 1.90 & 1.90 & 1.90 \\
\hline
\end{tabular}

*and ** indicates significance at $5 \%$ and $1 \%$ level respectively 


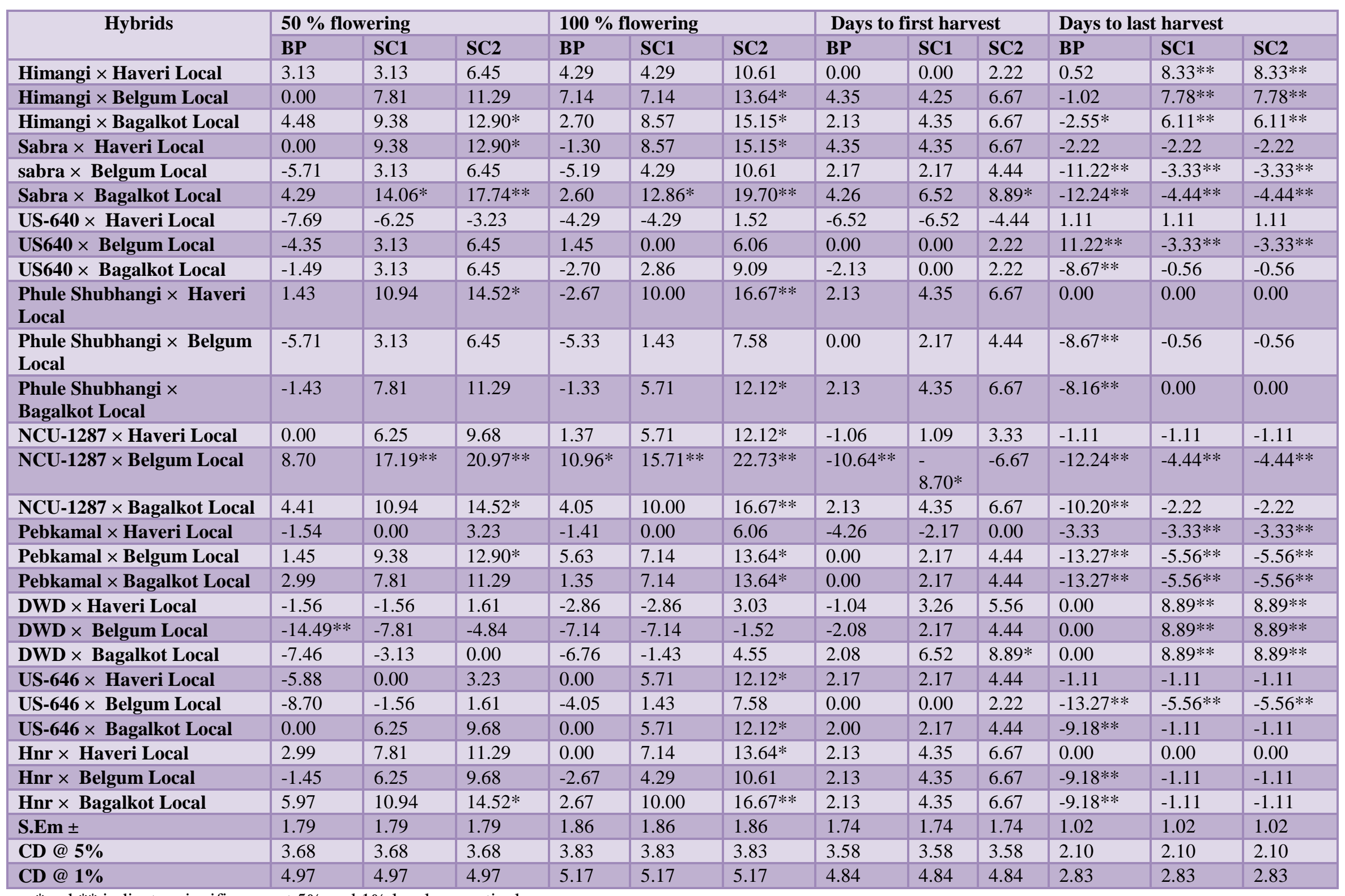

*and ** indicates significance at 5\% and $1 \%$ level respectively 
Table.2 Range of heterosis for earliness parameter in cucumber

\begin{tabular}{|c|l|l|l|l|}
\hline $\begin{array}{c}\text { Sl. } \\
\text { No. }\end{array}$ & \multicolumn{1}{|c|}{ Characters } & \multicolumn{1}{|c|}{ BP } & \multicolumn{1}{c|}{ SC1 } & \multicolumn{1}{c|}{ SC2 } \\
\hline $\mathbf{1}$ & Days to first male flower & -8.52 to 8.67 & -7.32 to 12.2 & -4.4 to 11.32 \\
\hline $\mathbf{2}$ & Node at male flower appear & -12.94 to 10.13 & -12.31 to 16.92 & -6.56 to 18.09 \\
\hline $\mathbf{3}$ & Days to first female & -7.27 to 8.7 & -7.8 to 8.64 & -1.49 to 11.61 \\
\hline $\mathbf{4}$ & Node at female flower appear & -18.33 to 13.21 & -28.83 to 41.46 & -15.91 to 13.82 \\
\hline $\mathbf{5}$ & 50\% flowering & -31.57 to 10.83 & -18.36 to 20.47 & -28.76 to 5.12 \\
\hline $\mathbf{6}$ & 100\% flowering & -25.25 to 50.93 & -33.64 to 48.85 & -37.39 to 40.43 \\
\hline $\mathbf{7}$ & Days to first harvest & -32.25 to 36.68 & -28.84 to 40.47 & -39.20 to 6.17 \\
\hline $\mathbf{8}$ & Days to last harvest & -3.33 to 1.11 & -2.22 to 1.11 & -2.22 to 1.11 \\
\hline & &
\end{tabular}

Note: BP - Better Parent; SC1- Standard Check 1 
The crosses Pebkamal $\times$ Haveri Local ($36.21 \%)$ and DWD $\times$ Belgum Local ($28.33 \%$ ) exhibited the significant heterobeltiosis in negative direction for node number at which first female flower appear. This is in accordance with the research findings of Bairagi et al., (2005), Hanchinamani and Patil (2009), Kumar et al., (2010), Singh et al., (2010) and Singh et al., (2015). The crosses exhibited the positive standard heterosis over superior checks and similar findings were reported by Dogra et al., (2011) in cucumber.

Negative heterosis for days to 50 per cent and 100 per cent flowering is desirable and indicated the earliness. Most of the crosses exhibited the negative heterobeltiosis and DWD $\times$ Belgum Local exhibited the significant negative heterosis over better parent for days to 50 per cent flowering, it is in accordance with research findings of Singh et al., (2013) in bitter gourd. None of the hybrids exhibited the significant negative heterosis over mid parent, better parent as well as over both the standard checks.

For days to first harvest negative estimates of heterosis is a well-recognized and prime objective of any breeding programme as it helps the grower to earn a good early market price (Airina et al., 2013). Heterosis in negative direction is desirable for days to first harvest. The cross NCU-1287 × Belgum Local exhibited the significant negative heterobeltiosis $(-10.64 \%)$ as well as standard heterosis $(-8.70 \%)$ over the check Poinsette (Table 1). This is in line with the research findings of Kumar et al., (2010) and Jat et al., (2015) in cucumber.

As days to last harvest increases, the number of harvest will be increases and finally it results in increase the yield. Heterosis in positive direction is desirable for days to last harvest. But range of heterosis (Table 2) for this trait is narrow in both direction and the crosses Himangi $\times$ Haveri Local, Himangi $x$ Belgum Local, Himangi $\times$ Bagalkot Local, DWD $\times$ Haveri Local, DWD $\times$ Belgum Local and DWD $\times$ Bagalkot Local exhibited the significant standard heterosis.

In conclusion, the results indicated that days to initiation of staminate and pistillate flowers varied from 39.4 to 51.17, and both staminate and pistillate flowers were first induced in genotype BG-11. The lowest ratio of staminate to pistillate flower was obtained in genotype BG-3. Staminate flowers initiated on the basal node namely 7 th and continued acropetally whereas pistillate flowers initiated from 11th node and continued onward. Small and round fruit bearing genotypes produced greater number of pistillate flowers. On the other hand, all genotypes produced the greater number of staminate flowers than pistillate flowers. Lesser number of fruit induced genotypes produced the larger individual fruit weight. The results also found variations in fruit quality attributes namely total soluble solid, ascorbic acid, $\beta$-carotene and protein content which created great potentiality for developing high yielding and quality bitter gourd through breeding.

\section{References}

Agbaje, G.O., Oloyede, F.M. and Obisesan, I.O., 2012. Effect of NPK fertilizer and season on the flowering and sex expression of pumpkin (Cucurbita pepo Linn.). International Journal of Agricultural Science. 2(11): 291-295.

Anonymous, 2015. Integrated horticultural manual. University of Horticultural Sciences, Bagalkot. pp. 95-97.

Arina, K.K., Pradeepkumar, T., George, T.E., Sadhankumara, P.G. and Krishna, S., 2013, Heterosis breeding exploiting gynoecy in cucumber (Cucumis sativus L.). Journal of Tropical Agriculture. 
51(1-2): 144-148.

Arya, K. and Singh, D.K., 2014. Exploitation of heterosis among parthinocarpic and monoecious genotypes of cucumber (Cucumis sativus L.) under polyhouse. International Journal of Basic and Applied Research. 12(1): 68-71.

Bhakti, P.B., Patel, N.B., Patel, A.I., Saravaiya S.N. and Tank R.V., 2016. Exploitation of heterosis in cucurbits. Innovative Farming, 1(3): 108-110.

Dogra, B.S., and Kanwar, M.S., 2011. Exploiting Heterosis for Yield and Horticultural Traits in Cucumber (Cucumis sativus L.). Indian Journal of Plant Genetic Resource. 24(3): 332339.

Hanchinamani, C.N. and Patil, M.G., 2009. Heterosis in cucumber (Cucumis sativus L.). Asian Journal of Horticulture. 4: 21-24.

Hayes, H.K. and Jones, D.F., 1916. First generation crosses in cucumbers. Connecticut Agricultural Experimental Station Annual Report. Rep: 19-322.

Jat, G.S., Munshi, A.D., Behera, T.K., Choudhary, H. and Dev, B., 2015. Exploitation of heterosis in cucumber for earliness, yield and yield components utilizing gynoecious lines. Indian Journal of Horticulture. 72(4): 494-499.

Kumar, J., Munshi, A.D., Kumar, R. and Surela, A.K., 2010. Studies on heterosis in slicing cucumber. Indian Journal of Horticulture. 67(2): 197-201.
Mule, P.N., Khandelwal, V., Lodam, V.A., Shinde, D.A., Patil, P.P. and Patil, A.B., 2012. Heterosis and combining ability in cucumber (Cucumis sativus L.). Madaras Agriculture Journal. 99(7-9): 420-423.

Pandey, S., Singh, B., Singh, M. and Rai, M., 2005. Heterosis in cucumber (Cucumis sativus L.). Vegetable Science. 32(2): 143-145.

Singh, A. and Ram, H.H., 2009. Standard hetrosis for yield and its attributing characters in cucumber (Cucumis sativus L.). Pantnagar Journal Research. 7(1): 81-84.

Singh, A.K., Pan, R.S. and Bhavana, P., 2013. Heterosis and combining ability analysis in bitter gourd (Momordica charantia L.). The Bioscan, 8(4): 15331536.

Singh, S.K., Kishor, G.R. and Srivastava, J.P., 2010. Commercial exploitation of hybrid vigour in cucumber. Progressive agriculture (Special Issue). (Special Issue), 10: 266-269.

Singh, S.K., Singh, S.V. and Srivastava, J.P., 2015. Studies on heterosis and inbreeding depression in cucumber (Cucumis sativus L.). Agriways, 3(2): 107-111.

Singh, R., Singh, A.K., Kumar, S. and Singh, B.K., 2012. Heterosis and inbreeding depression for fruit characters in cucumber. Indian Journal of Horticulture. 69(2): 200-204.

\section{How to cite this article:}

Prashant R. Naik, Nagarajappa Adivappar, V. Srinivasa and Gangaprasad, S. 2019. Testing of Hybrid Vigour for Sex Phenology in Cucumber (Cucumis sativus L.). Int.J.Curr.Microbiol.App.Sci. 8(02): 1923-1929. doi: https://doi.org/10.20546/ijcmas.2019.802.223 